This is an electronic reprint of the original article. This reprint may differ from the original in pagination and typographic detail.

Author(s): Ihalainen, Pasi; Ilie, Cornelia; Palonen, Kari

Title: $\quad$ Parliament as a Conceptual Nexus

Year: $\quad 2016$

Version:

Please cite the original version:

Ihalainen, P., Ilie, C., \& Palonen, K. (2016). Parliament as a Conceptual Nexus. In P. Ihalainen, C. Ilie, \& K. Palonen (Eds.), Parliament and Parliamentarism : A Comparative History of a European Concept (pp. 1-16). Berghahn books. European Conceptual History, 1.

All material supplied via JYX is protected by copyright and other intellectual property rights, and duplication or sale of all or part of any of the repository collections is not permitted, except that material may be duplicated by you for your research use or educational purposes in electronic or print form. You must obtain permission for any other use. Electronic or print copies may not be offered, whether for sale or otherwise to anyone who is not an authorised user. 


\section{Parliament as a Conceptual Nexus}

Pasi Ihalainen, Cornelia Ilie and Kari Palonen

Parliament has for centuries been a central European political institution for expressing dissensus and for conducting debates among the representatives of the citizens in a spirit of fair play. A modern parliament controls government and bureaucracy by claiming the right to make sovereign decisions without appeal. This volume builds on the thesis that deliberation (between opposed points of view in parliament), representation (of the citizens in a parliament), responsibility (of the government to the parliament) and sovereignty (of a parliament within a polity) form the core concepts of parliamentarism and distinguish a parliament from other types of assemblies, making it a unique representative institution. This cluster of distinguishing concepts of parliamentarism creates a clear agenda for the historical, discursive and political analysis of questions that all real parliaments face, more particularly so as each of these dimensions has been fiercely disputed in most European parliaments.

Parliament, parliamentarism and the cluster of parliamentary concepts constitute an excellent example of the essentially contested nature of political key concepts. Parliamentarism in any national context has been a product of a series of political disputes and has evolved further as a consequence of an ongoing process of political debate on its nature. It has become such a major feature of most European political cultures that such disputes and the consequent process of transformation in political systems have become tolerated.

This book is divided into three parts, each of which offers perspectives derived from different disciplines that contribute to present-day parliamentary studies, namely historical research (Part I, introduced in more detail in Chapter 1), discourse and rhetorical studies (Part II, introduced in more detail in Chapter 8) and political theory (Part III, introduced in more 
detail in Chapter 13). The discipline-specific approaches to parliamentary studies will be discussed in these introductory chapters. In this general introduction, we shall define the points of departure of our joint multidisciplinary volume, review the implications of an ideal type of parliament for our research and discuss some central features related to the naming of parliaments. We shall discuss the particularly European features of parliament as an institution, the methodological potential of multidisciplinary parliamentary studies of this type for renewing the research field of conceptual history and the potential of conceptual history for bringing added value to parliamentary studies.

After analysing the four conceptual dimensions of parliamentarism from the perspectives of history, discourse and political theory and drawing together the findings of this multidisciplinary project (which is done at a theoretical level in this introduction and on the basis of empirical studies in Chapters 1, 8 and 13), we should be able to better understand the development of European parliamentarism in long-term comparative and multidisciplinary perspectives. This book explores the mutual relationships between the proposed four dimensions of parliamentarism in various historical periods from the French Revolution to the (re-)parliamentarization of Central and Eastern Europe and the attempted parliamentarization of the European Union through the analysis of national cases, varying from Britain and Finland to Russia and Spain. Side by side with deliberation, representation, responsibility and sovereignty, we also consider other concepts that have played central roles in conceptualizing parliament in modern European history.

The studied period is a long one, covering over two hundred years. From the point of view of conceptual history, parliamentary concepts do not change in successive stages or fashions in a linear way; rather, novelties are frequently combined with actualizations of old topoi. In order to make this recycling of past parliamentary experiences and momentums visible, parliamentary history needs to be studied in a long-term perspective. In present-day 
parliaments, for instance, we can distinguish different conceptual layers that can only be recognized and understood against the background of an extended time frame and by combining the tools of various disciplines. It is important to identify the political situations to which these layers were originally connected and to see how they have been further developed in differing political contexts. The rhetorical use of concepts by various political agents in the past has opened new horizons for research and debate. Both explicit and highly controversial conceptual changes and less visible and unintended ones in the course of parliamentary history need to be considered in relation to each of the parliamentary dimensions.

In this volume, we focus on debates about the character of parliament and parliamentarism within different European parliaments, countries and genres of writing as one of the first comparative steps in conceptual history. In doing so, we integrate transnational elements into the analysis as far as possible. Eventually, we aim to identify the momentum of parliamentarization in terms of various aspects of parliamentarism in different national contexts - for example, the momentum of extended popular representation in a parliament or governmental responsibility to a parliament - with each momentum initiating a political point of reference for later parliamentary history. We argue that the key periods of parliamentarization in the history of several European countries include the French Revolution, which started in 1789; the parliamentarization of government and the extension of parliamentary suffrage from the 1830s to the last phase of the First World War and its immediate aftermath; the rearrangements that followed the Second World War; and the fall of the Soviet bloc starting in 1989.

On the other hand, the schedule of parliamentarization has varied from country to country, and its 'progress' has been anything but steady. The French Revolution created a break with the tradition of estate assemblies not only in France but also in other countries, 
offering an alternative to the older British parliamentary and continental estate models for how representative institutions in an increasingly democratic polity should be organized. The period from the mid 1860s to the early 1870s was another period of reform, expressed in the extension of suffrage (Britain and Germany), the parliamentarization of government (France) and the replacement of the estate system with a modern type of parliament (Austria-Hungary and Sweden). The breakthroughs that representative democracy made in several European countries (and not only in newly independent states) during and in the immediate aftermath of the First World War opened entirely new prospects for parliamentary democracy, even if overly optimistic expectations failed to be realized in the nationalistic and often totalitarian atmosphere of the interwar period. The return to parliamentary government with an almost exclusive emphasis on the responsibility criterion was followed without any greater debate on parliamentary principles after the Second World War, in West Germany, Italy and in Western European countries that had been occupied during the war. Four decades later, the historic changes brought about by the collapse of communism in Eastern Europe in 1989 propelled parliaments in post-communist regimes from pseudo-parliamentary or quasi-parliamentary institutions into key political players as democratically functioning representative and deliberative bodies.

We can, to some extent, build on studies in parliamentary history that have manifested themselves in Europe in recent years. Recent works with a comparative ambition include Christoph Gusy's Demokratie in der Krise: Europa in der Zwischenkriegszeit (2008), although it is limited in terms of both its chronological and thematic scope. Two volumes compiled from presentations at conferences organized by the German Commission for Parliamentary History and Political Parties (KGParl) and the historians of the Humboldt University in Berlin have opened a series on comparative parliamentary history in German, discussing parliamentary cultures in a long-term perspective, albeit on the basis of loosely 
connected cases and bypassing most conceptual, discursive and theoretical aspects of parliamentarism (Schulz and Wirsching 2012; Feuchter and Helmrath 2013). A third volume, based on a conference in The Hague in 2013, is expected to discuss parliamentary ideals in a comparative European perspective.

The study of parliamentary discourse and practices has acquired real interdisciplinary scope only recently as a result of contributions made by scholars from the linguistic subdisciplines, such as pragmatics, critical discourse analysis and rhetoric and cognitive linguistics. Paul Bayley’s edited book Cross-Cultural Perspectives on Parliamentary Discourse (2004) is a pioneering endeavour that displays the use of several methodological frameworks for the analysis of parliamentary discourses in different countries (Britain, Germany, Italy, Mexico, Spain, Sweden and the United States). A broad spectrum of interdisciplinary perspectives is used in Cornelia Ilie's volume European Parliaments under Scrutiny: Discourse Strategies and Interaction Practices (2010a) to examine and problematize the impact of parliamentary debating practices and linguistic strategies on current political action and interaction in parliaments across Europe, including postcommunist parliaments.

In political theory, we can speak of a renaissance of studies on the concepts of 'political representation' and 'representative democracy' (e.g., Urbinati, Representative Democracy: Concept and Genealogy, 2006), although a tendency to make everything 'representation' and thus to depoliticize the concept is fashionable (see Saward, The Representative Claim, 2010). A critique of concepts of governance, depoliticization and a discussion of the 'crisis of representation' is contained in Danny Michelsen and Franz Walter's work, Unpolitische Demokratie: Zur Krise der Repräsentation (2013). Nicolas Roussellier's Le Parlement d'Éloquence (1997) and later studies may represent the first initiatives for rehabilitating the parliamentary culture of the French Third Republic and the 
rhetorical dimension of parliamentary politics in general (see Finlayson, 'Rhetoric and the Political Theory of Ideologies’, 2012; Galembert, Rozenberg and Vigour 2014; and Palonen, Rosales and Turkka 2014). The political aspects of parliamentary procedure have also regained interest among scholars (see Clinchamps 2006; Sanchez 2012; Palonen 2014). A renewed interest in parliaments as such, beyond governments and parties, can be seen in more empirical studies in political science, for example in Germany around the work of Werner J. Patzelt (see 2005, 2012; Patzelt and Dreischer 2009).

However, this is the first work that aims to create a comparative conceptual history of European parliamentarism. Instead of attempting to be completely comprehensive with regard to all European parliaments or all aspects of their conceptual history, this book consists of a selection of representative national and regional case studies written by leading experts in the field. The primary units of comparison are the national parliaments themselves, complemented by a separate chapter on the European Parliament together with some discussion of inter-parliamentary transfers. The selected cases are used to demonstrate central features in the development of parliamentarism as a pan-European phenomenon in key historical periods since the French Revolution. Most of the European great powers were involved in some formative historical period that produced turning points in the history of parliamentarism. Most of the other European regions are represented by illustrative national cases from smaller countries. It goes without saying that not all national histories of parliamentarism can be covered within the confines of this survey volume.

The parliamentarization of representative governments across Europe implies the conceptualization of a definite change in political cultures. This change has taken place rapidly in some national contexts, and it is also applicable to cases such as the replacement of Soviet-style facade assemblies by proper parliaments after 1989. The parliamentary experience, vocabulary, representation and procedures of deliberation to some extent tend to 
create transnational rather than purely national parliamentary political cultures, and in them the parliamentary language transcends the vernacular 'dialects'. The processes of conceptual transfer and translation concern the relationships between the general parliamentary language and its national 'dialects'. Parliaments use vernacular languages, and they are formed on a national basis, serving as symbols of the transcendence of sub-national particularities. Even if transfers between national parliaments are not self-evident and can imply considerable change in new contexts, parliaments nevertheless have numerous features in common. Supraand transnational parliamentary assemblies can be expected to have a growing importance in institutions such as the EU and the UN, and this further increases the possibilities for transnational and inter-parliamentary transfers.

Having provided the first expressions of many parliamentary concepts in the past, the British and French parliamentary cultures play, to some extent, a double role in the development: in them parliamentary concepts and national political traditions have been intertwined more closely than in the case of the latecomers, who have adopted elements taken from these two models. Appropriating the elements of parliamentary culture from these countries and applying them to new contexts have taught the political elites of other countries parliamentary styles of debating. Of course, we should not overemphasize the possibilities for transfer in parliamentary language, as foreign models and references have usually been adopted selectively and even tendentiously in order to serve particular purposes in domestic circumstances (more on this in Chapter 1). Seemingly conceptual transfers between parliamentary cultures do not imply that applications necessarily carry similar meanings in different political cultures.

Parliament and parliamentarism remain concepts of dispute. Unlike, for example, the concept of democracy, which has taken on consistently positive (though still contested) meanings in the course of the twentieth century, the concept of parliamentarism has never 
received universal approval. Not only do its key content and range of reference remain highly contested, but so do its value and its conditions of realization. The phrase 'crisis of parliamentarism' was coined in France at the time of the Third Republic in the late nineteenth century, and since then it has been a recurrent topos evoked from different political corners and for varying purposes (for current challenges to parliamentarism, see the Epilogue in this book). Constant contestation and an atmosphere of crisis have become essential elements of European parliamentarism. Indeed, parliamentarism should perhaps be seen as a long-term discursive process of disputes and crises that moves in time and space rather than a sort of goal that could be achieved at some specific moment in history.

\section{The Ideal Type of Parliamentarism}

As was pointed out at the start, our hypothetical point of departure consists in the construction of a four-dimensional ideal type of parliament, comprising a cluster of concepts held together by parliament itself as a political concept. Each of the dimensions has been fiercely disputed among members and constitutes a criterion that distinguishes a parliament from other types of assemblies and institutions. The dimensions of representation, deliberation, sovereignty and responsibility set the agenda for the historical study of the concept of parliament, a concept that is used by political agents and writers on politics alike.

The dimension of representation refers to parliament as a permanent assembly regularly summoned to represent and act in the name of the citizenry and chosen at regular intervals in free and fair elections. The permanence of parliament, the regularity of its sessions, its representative character and the recurrent election of its members together with the freedom and fairness of its elections can be regarded as constitutive criteria for the distinction between parliamentary and non-parliamentary types of representation. The inclusion of the citizenry, the franchise and eligibility of the citizens, the density and rhythm 
of elections and of the parliamentary sessions, the modes of conducting free and fair elections and so on then constitute the intra-parliamentary range of variation in the parliamentary representation. In addition, we can speak of non-parliamentary modes of representation; these include the old estates, corporative forms of representation, the council type (wards, communes, soviets, etc.) of assemblies, presidential and plebiscitary regimes, and perhaps also the non-elective forms of selecting representatives; for example, by rotation or lottery (see Chapter 13 and the Epilogue for further discussion). Parliaments in this volume are not early modern estate assemblies, debating societies or local or regional assemblies. They are deliberative assemblies based on modern conceptions of the representation of the people. Some other forms of government, such as presidential regimes, have been excluded. Even though the estate assemblies provided the basis on which several modern representative institutions were built, and even though some features of them survived in the upper chambers of many nineteenth-century parliaments, we have chosen not to focus on the analysis of their proto-parliamentary features but have nevertheless paid attention to trajectories in thought and practice derived from the traditions of the representation of the estates.

The dimension of deliberation refers to a characteristic of parliament that is founded on the basic principle of a debating assembly, in utramque partem disputare. The construction of the distinct parliamentary form of procedure consisting of questions dealt with systematically from opposite perspectives and disputed between the members marked a procedural and institutional innovation that was unknown in the ancient and medieval forums of deliberative rhetoric. In a parliament, the opponents sit in the same auditorium; they are insiders, not outsiders - every speech is persuasively structured and every vote is a challenge to existing political configurations. The principles of a free mandate, free speech, freedom from arrest (parliamentary immunity) and free elections are preconditions for the proper 
functioning of a deliberative assembly. Parliamentary 'government by speaking' (Thomas Babington Macaulay) is opposed to violent confrontation as well as to silent assemblies that have only the right to vote: the parliamentary vote is the last act in the process of deliberation. Parliaments are thus also conceptually opposed to the notion of merely ratifying assemblies.

The main topics of controversies pertaining to the deliberative dimension of parliament are related to such matters as the procedures for setting the parliamentary agenda, the relationship between the government and parliament and the relationship between the plenum and the committees. Further issues can include such topics as the fair distribution of parliamentary speaking times, the powers of the Speaker regarding, for example, the demarcation between free speech and unparliamentary conduct, the rhetorical styles of parliamentary speaking, manners of addressing members in parliament and the recognition of the existence of parties without turning parliament into a mere 'congress of ambassadors' (Edmund Burke).

The sovereignty of a parliament is historically opposed to the royal or presidential prerogatives and to the interpretative power of the courts of law over parliamentary decisions, as legitimized by the doctrine of the separation of powers. The current theoretical debate concerns the compatibility of parliamentary sovereignty with written constitutions and extraparliamentary vs. intra-parliamentary modes of resolving constitutional disputes. Arguments over parliamentary sovereignty have also arisen in neo-corporative contexts with regard to the imposition of extra-parliamentary decisions (involving labour-market partners and various kinds of lobbyists) on parliaments, leaving it with a merely ratifying role. The intraparliamentary dimension of sovereignty disputes concerns the demarcation of powers between parliaments. The sovereignty thesis has been applied to national parliaments, while sub- and supranational assemblies have not been treated as parliaments proper by scholars or politicians. With the relativization of national sovereignty in relation to both supra- and sub- 
national units, the main issue regards the parliamentary forms of deliberation and decisionmaking in any representative and responsible assembly, and the relations of the parliament to the government and the judiciary. Of special interest here is, of course, the European Parliament, whose increasing powers are, however, far from sovereign (see Chapter 18).

The responsibility of the government to the parliament is the key political issue in the history of parliamentarism in that it distinguishes parliamentary from non-parliamentary regimes. The power to exert budgetary control and to both elect and dismiss a government represent the main steps in the history of the parliamentarization of government. In this respect, parliamentary government is also opposed to plebiscitary procedures, which submit parliamentary decisions to referenda. A majoritarian interpretation of parliamentary government, which holds election results to be decisive, contains a presidential dimension in the election of the prime minister and attempts to reduce the parliament to a merely ratifying institution (acclamatio). Multiparty coalition governments insist on negotiation between parties, which tends to limit the political freedom of members. By contrast, a more deliberative view insists on the parliamentary control and accountability of the administration and the powers of the members of parliament as a counterweight to the government and the administration.

\section{Naming Parliaments}

Parliament is usually a common noun and very seldom the proper name of a parliament. The different aspects of the conceptual struggle have been projected onto the names of national parliaments. Parlamentum has been known as a name for negotiations between powerful men since the twelfth century. It, of course, refers to speaking - parlare in Italian, parler in French - although parlementaire originally referred to a negotiator between parties in war and diplomacy. It took a long time for parliaments to evolve from contingent occasions to 
regular and recurrent assemblies of members and even longer for their members to become elected representatives.

The estate assemblies are called diets, a word derived from the Latin dies (day) and originally meaning the day(s) of assembly. The same kind of derivation is still represented today in the German Landtag and Bundestag and the Swedish Riksdag. The Dutch Staten Generaal and the Spanish Cortes originally referred to the names of estate assemblies but have been retained for the modern parliaments. The nomenclature referring to assemblies Assemblée nationale, Nationalvergadering, Nationalversammlung and the like - refers to the meeting itself, with an interesting nuance that the Weimar 1919 assembly was at the same time a constituent assembly and an 'ordinary' parliament. The old Scandinavian ting - out of which the Danish Folketing, Norwegian Storting, Icelandic Allting (all assemblies composed of 'the people') and Lagting of the autonomous Faroe Islands and the Åland Islands are derived - originally referred to an assembly that debated public affairs and not to a court of law as in later times. The Russian Duma has a similar connotation.

The U.S. House of Representatives refers even more explicitly than national assembly to the 'representative' character of the assembly, as does the Finnish Eduskunta. The names of the chambers refer to those who are represented, although the word 'senate' (derived from the ancient Roman name for the assembly of the nobles, senatus, which literally meant a council of elders - seniores) is still used in the United States, France, Italy and Belgium, for example, and it sometimes even has a higher qualification age than the 'lower house'. The fact that the 'lower' or 'popular' house (sometimes also the 'second' chamber, as in the case of the Dutch Tweede Kamer), as a rule, is more powerful than the higher one (the U.S. House of Representatives is the great exception) is an interesting move of paradiastolic redescription (in the sense of Skinner 2007). Or, in Walter Bagehot's terms, the upper house refers to the 'dignified' and the lower to the 'efficient' aspect of parliamentary politics. 
The advisory nomenclature of 'council' is seldom used for parliamentary institutions, although monarchs, in particular, sought to retain them as consultative institutions for a long time. Rather, the vocabulary refers to governmental institutions, including slightly paradoxically the soviets, which originated as workers' councils, Arbeiterräte, etc. However, as a result of the rejection of the division between executive and parliamentary powers, they accepted a title corresponding to the council of royal advisors, and were soon reduced to an advisory position in relation to the party and the state administration.

If we insist on the political control of government and administration, parliament seems a better name than the other alternatives. Using Alfred O. Hirschman's terminology (1970), a parliament expresses a voice, as opposed to exit (non-voting, boycott of parliamentary sittings, used for example by the Sinn Fein members in Britain after 1919) and loyalty (acclamation) as alternative modes of acting.

\section{Analysing Parliamentarism as a Way to Understand Europe}

This volume is one of a series titled European Conceptual Histories. We argued in the beginning that both parliament as an institution and the parliamentary style of politics are distinctively European. The origins of the parliamentary style of politics lie in the historical formation of specific parliamentary procedures, rhetorical cultures and later forms of government, first in England/Britain since the early modern period and then in France from the Revolution of 1789 onwards. In some countries (the Netherlands, Sweden, Finland and Poland) the early modern estate diets were transformed into parliaments after the late eighteenth century, and major conceptual revisions and inter-parliamentary transfers were also involved in these processes.

The nineteenth century was a period that saw the introduction and reform of national parliaments throughout much of Europe. By the 1920s practically every European country 
had had an experience of at least rudimentary parliamentary institutions. The powers of parliaments were fiercely debated both in parliamentary and non-parliamentary regimes, especially during the 'crisis of parliamentarism' in the 1920s and 1930s. The revival of parliaments was, however, a major feature of the breakdown of fascist and communist dictatorships in 1945, the 1970s and between 1989 and 1990. Re-parliamentarization offers a fresh perspective on the comparative conceptual history of the overthrow of dictatorships (see Chapter Twelve as well as Ilie 2010b and Ornatowski 2010). Furthermore, the attempted parliamentarization of the EU can also be analysed from this perspective. International networks have also been created recently for the strengthening of parliaments as an inherent part of development programmes: the Europeans continue to export the idea of parliament and parliamentarism beyond their own continent.

The parliamentary regime can legitimately be seen as characteristically European: outside Europe, with the exception of most former British colonies, the presidential model of democracy without parliamentary responsibility and sovereignty prevails, and also the procedure of dissensual deliberation is mostly viewed with suspicion. The debate between parliamentary, presidential or semi-presidential (France) and semi-plebiscitarian regimes (Switzerland) has been one of the main dividing issues in European politics from the nineteenth century onwards.

Most Europeans today share a legacy of government by representation and discussion. Historically, the tacit and gradual formation of a specific parliamentary manner of deliberation, debate and decision-making has created a distinct parliamentary procedure. It has distinguished parliamentary and unparliamentary forms of conduct and speech and created a distinct parliamentary vocabulary by producing new, specifically parliamentary terms by giving other words and phrases a distinctly parliamentary meaning. The main features of parliamentary procedure are widely shared by all parliamentary regimes and to a 
large extent by non-sovereign parliaments and assemblies. In short, parliamentary culture(s) with largely shared albeit contested concepts at the same time provide occasions for strategic innovations and national variations in the parliamentary use of these concepts throughout Europe. Parliaments can, furthermore, serve as a model for various fields of political culture with regard to the conduct of meetings and debating. Parliaments are a European cultural feature of primary importance.

Owing to growing collaboration between national and European institutions, the role of national parliaments in the process of consolidating a common European public sphere and the convergence of integrationist goals have been further reinforced. Through institutionally and culturally based communication practices, members of national parliaments and members of the European Parliament contribute to discursively shaping and reshaping their own nations’ relationship with past, present and future European values.

\section{Updating Conceptual History through Parliamentary Studies}

In the existing conceptual historical lexica such as the German Geschichtliche Grundbegriffe: Historisches Lexikon zur Politisch-Sozialen Sprache in Deutschland (8 vols: Koselleck, Brunner and Conze 1972-97), or in almost any other national project in conceptual history, studies on parliament and parliamentarism have been lacking or hidden behind other concepts such as representation or democracy. Both the traditional history of political thought and social history, which have shaped the existing versions of conceptual history, have shown little interest in parliaments or in the cluster of concepts that define them. However, parliamentarism is for conceptual history, as a highly language-conscious approach to the analysis of political history and theory, a central topic for research, as it has largely been based on speaking and active debate by past political actors. Conceptual history can make 
visible the dynamics of parliamentary debate as well as the variety of views on the current problematics, which the discursive processes in parliaments have produced.

Histories of parliaments have mainly remained at a national level, bypassing comparisons and transnational transfers and ignoring conceptual aspects, preferring to focus on structures, functions, events, ceremonies and so on. The regime aspect of parliamentarism has tended to be studied rather narrowly in constitutional law and political science, while linguistic, discourse and rhetorical studies have used parliamentary debates mainly to illustrate some general problems of discussion and debate. The emerging new studies on the cultural history of parliaments (especially in the Netherlands) and political communication (especially in Germany), though highly interesting, usually focus on parliamentary debate and concepts and their histories.

Based on historical, discourse and political theory analysis, this volume concentrates on the key vocabulary of parliamentary politics in relation to parliament itself as well as its quasi-synonyms and antonyms. It discusses the four conceptual dimensions of parliament delineated in the initial thesis, as well as a representative repertoire of concepts and terms indicative of the major controversies relating to the conceptual history of parliament itself. The key concepts of parliamentarism and the repertoire of related concepts have offered us signposts for identifying significant debates on these concepts in parliaments themselves and for searching for exceptional but noteworthy uses of these concepts in parliamentary debates and in parliament-related publications. The relative (though far from complete) similarities between the specific parliamentary concepts across national political cultures make it easier to apply them in a comparative analysis across different languages and official rules and regulations.

Parliamentary debates themselves, especially digitized ones whenever available, serve as primary sources for the conceptual analysis of parliamentarism, whether viewed from the 
point of view of history, discourse research or political theory. The main advantage of using parliamentary sources in conceptual history is that in parliamentary debates concepts are used as 'moves in argument' (Skinner 1988: 283), and they become topical only when they are disputed. Thus parliamentary concepts are an integral part of controversies about parliamentarism. Conceptual historical studies are part of the rhetorical analysis of debates, but they concentrate on the conceptual controversies, analysing them from historical and comparative perspectives and rendering them explicit (see Ihalainen and Palonen 2009).

The availability of public parliamentary records in most European countries (often in a recently digitized form) offers promising new opportunities for a comparative conceptual history of parliaments. The main 'methodological' problem for conceptual histories of parliament and parliamentary concepts lies in the huge extent of the available primary sources. The subject indexes of the printed works and the search engines of the online textual corpora can, of course, simplify the task. Conceptual historical research based on parliamentary documents requires above all a distinct 'parliamentary literacy' that focuses on the formal and procedural character of parliamentary debate, the item that is being studied, previous debates, key concepts, discursive practices, long-term theoretical debates and the like. Such a literacy provides more general guidelines on what disputes to study, how to read parliamentary sources and how to reflect on this reading in the framework of a conceptual historical study.

Another methodological challenge lies in connecting the case studies (on a national, regional or linguistic areal basis) with the general topoi of parliamentarization. Our aim is to link the case studies to the main problematics both by comparing national similarities and differences with general European trends and by contrasting the studies with those of other national cases - both closely related and highly divergent ones. The objects of comparison can then be national political cultures and historical periods and also the dimensions of the 
concept of parliamentarism and the three disciplinary aspects (historical, discursive and theoretical) of the analysis of parliamentary politics to which this volume is devoted. Through such contrasts and parallels, the chapters of this book reveal different profiles of the parliamentary concepts and the different rhythms of their historical change, rather than merely presenting national or regional histories with a parliamentary emphasis. The result is, we hope, not a history of national parliamentary institutions in Europe, but a conceptual and rhetorical history of European parliamentarism.

Furthermore, by concentrating as far as possible on parliamentarians' reflection on the character and political role of parliament and parliamentarism, we can search for typical instances of potential conceptual change. Disputes on parliamentary, constitutional and electoral reforms together with votes of no confidence often offer major occasions of debate. Similarly, debates based on governmental statements to parliaments, on the organization of parliamentary procedures themselves and on the status of members of parliament serve as further paradigmatic situations of conceptual dispute that are of particular importance for the conceptual history of parliamentarism. Debates of this character have been regularly, or at least occasionally, conducted in all European parliaments, and they involve the different dimensions of parliamentary politics. On the other hand, any item on the parliamentary agenda can give rise to conceptual debates, and the goal of the various case studies has been to detect some of the most significant controversies relating to parliamentarism.

Complementary to parliamentary debates and documents as sources for the conceptual history of parliament are other contemporary extra-parliamentary texts. In addition to academic, journalistic and literary writings, we can mention textbooks on rhetoric, and ‘manuals’ like William Gerard Hamilton’s Parliamentary Logic (1927 [1808]). They can explain the significance of some parliamentary debates or the conceptual struggles involved in them; on the other hand, the conceptual innovations and revisions contained in debates can 
be better analysed by focusing on the debates themselves. Academic discussions and subsequent studies of parliamentary institutions may be valuable for the conceptualization of parliamentary changes that were not properly understood by the contemporary agents themselves.

\section{Summary of the Idea of the Book}

In the following three parts and their respective chapters, the key elements of parliamentarism - representation, deliberation, sovereignty and responsibility - will be analysed by means of empirically oriented research in the disciplines of history, discourse analysis and political theory. Owing to the lack of any existing comprehensive diachronic or synchronic analyses of the conceptual history of parliament and the key parliamentary concepts, the present volume inevitably has the character of an overview. The purpose is both to review existing research and other forms of available information (mainly in parliamentary records) on the conceptual history of parliament in a synthesizing manner, and to reconsider the distinct history and specific political significance of the concept of parliament and thereby open up vistas for further research on the conceptual history of parliament and parliamentarism.

\section{Note on Translations}

All translations are by the authors if not otherwise indicated.

\section{References}

Bayley, P. (ed.). 2004. Cross-cultural Perspectives on Parliamentary Discourse. Amsterdam and Philadelphia: John Benjamins.

Clinchamps, N. 2006. Parlement Européen et Droit Parlementaire. Essai sur la Naissance du Droit Parlementaire de l'Union Européenne. Paris: LGDJ. 
Feuchter, J. and J. Helmrath (eds). 2013. Parlamentarische Kulturen vom Mittelalter bis in die Moderne. Reden - Räume - Bilder. Düsseldorf: Droste Verlag.

Finlayson, A. 2012. 'Rhetoric and the Political Theory of Ideologies', Political Studies 60(4): 751-67.

Galembert, C. de, O. Rozenberg and C. Vigour, (eds). 2014. Faire Parler le Parlement. Méthodes et Enjeux de l'Analyse des Débats Parlementaires pour les Sciences Sociales. Paris LGDJ.

Gusy, C. 2008. Demokratie in der Krise: Europa in der Zwischenkriegszeit. Baden-Baden: Nomos.

Hamilton, W.G. (1927 [1808]). Parliamentary Logic, with an Introduction and Notes by Courtney S. Kenny. Cambridge: Heffer.

Hirschman, A.O. 1970. Exit, Voice, and Loyalty: Responses to Decline in Firms, Organizations, and States. Cambridge, MA: Harvard University Press.

Ihalainen, P. and K. Palonen. 2009. 'Parliamentary Sources in the Comparative Study of Muotoiltu: suomi Conceptual History: Methodological Aspects and Illustrations of a Research Proposal', Parliaments, Estates \& Representation 29(1): 17-34.

Ilie, C. (ed.). 2010a. European Parliaments under Scrutiny: Discourse Strategies and Interaction Practices. Amsterdam: John Benjamins.

Ilie, C. 2010b. 'Managing Dissent and Interpersonal Relations in the Romanian Parliamentary Discourse', in C. Ilie (ed.), European Parliaments under Scrutiny: Discourse Strategies and Interaction Practices. Amsterdam: John Benjamins, pp. 193-222.

Koselleck, R., O. Brunner and W. Conze (eds). 1972-97. Geschichtliche Grundbegriffe: Historisches Lexikon zur Politisch-Sozialen Sprache in Deutschland, 8 vols. Stuttgart: KlettCotta. 
Michelsen, D. and F. Walter (eds). 2013. Unpolitische Demokratie: Zur Krise der Repräsentation. Berlin: Suhrkamp.

Ornatowski, C.M. 2010. 'Parliamentary Discourse and Political Transition: Polish Parliament after 1989', in C. Ilie (ed.), European Parliaments under Scrutiny: Discourse Strategies and Interaction Practices. Amsterdam: John Benjamins, pp. 223-64.

Palonen, K. 2014. The Politics of Parliamentary Procedure: The Westminster Procedure as a Parliamentary Ideal Type. Leverkusen/London: Budrich.

Palonen, K., J.M. Rosales and T. Turkka (eds). 2014. The Politics of Dissensus: Parliament in Debate. Santander: McGraw Hill and University of Cantabria Press.

Patzelt, W. (ed.). 2005. Parlamente und Ihre Macht. Baden-Baden: Nomos.

Patzelt, W. (ed.). 2012. Parlamente und Ihre Evolution. Baden-Baden: Nomos.

Patzelt, W. and S. Dreischer (eds). 2009. Parlamente und Ihre Zeit. Baden-Baden: Nomos.

Roussellier, N. 1997. Le Parlement d'Éloquence. Paris: Sciences-po.

Sanchez, S. 2012. Les Réglements des Assemblées Nationales 1851: Naissance du Droit Parlementaire Moderne. Paris: Dalloz.

Saward, M. 2010. The Representative Claim. Oxford: Oxford University Press.

Schulz, A. and A. Wirsching (eds). 2012. Parlamentarische Kulturen in Europa: Das Parlament als Kommunikationsraum. Düsseldorf: Droste Verlag.

Skinner, Q. 1988. 'A Reply to My Critics’, in J. Tully (ed.), Meaning and Context: Quentin Skinner and His Critics. Cambridge: Polity, pp. 231-88.

Skinner, Q. 2007. 'Paradiastole: Redescribing the Vices as Virtues’, in S. Adamson, G. Alexander and K. Ettenhuber (eds), Renaissance Figures of Speech. Cambridge: Cambridge University Press, pp. 147-63. 
Urbinati, N. 2006. Representative Democracy: Concept and Genealogy. Chicago: University of Chicago Press. 